\title{
Effect of Cell - Free Cultures Filtrates of Different Bacterial Isolates on Seed Germination and Seedling Growth of Parkinsomia aculeata $\mathbf{L}$.
}

\author{
Sanaa, A. I. Moussa* and Huda M. Sheikh, \\ Botany \& Microbiology Department, ' Science Faculty, Cairo \\ University, Giza, Egypt. and Biological Science Department, \\ Science Faculty for Girls, ${ }^{* *}$ King Abdulaziz University, Jeddah \\ 21589, Saudi Arabia.
}

\begin{abstract}
R ACTERIAL species produce a variety of beneficial metabolites for plant growth and survival, as well as defend their hosts from attack of certain pathogens. The present study was carried out to investigate the impact of different bacterial isolates on the seed germination and seedling growth of Parkinsomia aculeata L. as a species of arid zones. Both soil samples and tested seeds were collected from El-Madina El-Monawara city, Saudi Arabia in May, 2013. Results evinced the promotion of seed germination by all bacterial isolates used. Isolates 6 and 7 (Micrococcous sp. and Sporosarcia sp.), respectively isolated from soils of extremely low salinity recorded the highest values of germination percentage (44 and 48). On the same time, the greater seed vigor index (83.04), and energy of germination (1.96) were given by isolate 7 at the $7^{\text {th }}$ day of the experiment. On the other hand, the highest R/S ratio (0.55), on the basis of length, and the highest dry weight of root and shoot were attained by Bacillus subtilis isolate.
\end{abstract}

Keywords: Bacteria - Germination index - Filtrate - Seedling vigor.

Seeds of leguminous plants are characterized by their possession of hard coats. Germination of many seeds is retarded only by impermeable coats which hinder the admission of water. If these coats are not subjected to pretreatment, germination can be erratic and prolonged, sometimes extending over a period of many years (Fordham, 1965). However, very little is known about plant growth stimulates produced by bacterial species in leguminous plants. Naturally, soils are ultimately rich habitats in active microorganisms; including bacteria which interact with their metabolites such as Indole Acetic Acid (IAA) produced by Bacillus sp. (Josic et al., 2013), nitrogenase (Das and Kole, 2006), soluble phosphate (Vastakaite and Buzaite, 2011 and Ajilogba et al., 2013) and ammonia (Yadan et al., 2010) that are effective in decaying the seed hard coats and promoting seed germination and seedling growth. Therefore, the objective of this

*Corresponding author: shamahmoh@gmail.com 
study is to investigate the potential of soil bacterial culture filtrate on seedling growth of Parkinsomia aculeata L.

\section{Material and Methods}

Soil samples were collected from El-Madina El-Monawara city, Saudi Arabia at different localities: Qurban El Nazel, Eastern Hara, Western Hara, Allawy and Ohod Mountain, Soils were air - dried and kept at $25^{\circ} \mathrm{C}$. Mechanical analysis of the collected soil samples (texture), $\mathrm{pH}$, and electric conductivity (EC) were estimated.

The bacterial isolates were identified according to Bergey's Manual of Systematic Bacteriology (1984) Sneath et al. 1986 and Sheikh, (2010). Bacterial isolates were maintained on nutrient broth medium: Beef extract $(0.3 \mathrm{~g}$ minerals and carbohydrates), peptone ( $0.5 \mathrm{~g}$ proteins as nitrogen source), $0.5 \mathrm{~g} \mathrm{NaCl}$ as an electrolyte and $100 \mathrm{ml}$ distilled water. The $\mathrm{pH}$ of the medium amounted 7 . The cultures were kept at $4{ }^{\circ} \mathrm{C}$ for further studies. For crude bacterial filtrate preparation, $1 \mathrm{~g}$ of soil was inoculated into Erlenmeyer flasks $(250 \mathrm{ml})$ containing $100 \mathrm{ml}$ of the nutrient broth. Culture broth flasks were incubated at 20 $\pm 2^{\circ} \mathrm{C}$ for 10 days. Bacterial filtrate was collected by filtration through sterilized bacterial filters (NALGENE $0.45 \mathrm{~mm}$ ) produced by Nalge Nunc International (Umechuruba and Nwachukwa, 1997) and was stored at $4^{\circ} \mathrm{C}$ for further use. An experiment was designed to test the biological activities of the cell - free culture filtrate of soil bacteria on the seed germination and growth of Parkinsomia aculeataL. (Leguminosae) seeds in vitro. Seeds were soaked in each bacterial filtrate for $30 \mathrm{~min}$. for each treatment. For control, seeds were soaked in distilled water. 25 seeds for each treatment were placed in $90 \mathrm{~mm}$ diameter Petri dishes on Whatman No.1 filter paper moistened with $5 \mathrm{ml}$ of sterile filtrate, or distilled water for the control. Treated seeds were incubated at $25^{\circ} \mathrm{C}$ under dark conditions. Germination progress was recorded daily with the addition of $2 \mathrm{ml}$ filtrate. The germination percent (GP) of germinated seeds was recorded after 7 days of planting (ISTA, 1993 and 1999). At harvesting, the seedling height, root and shoot lengths, dry weights of the roots and shoots, seed germination index (SGI), seedling vigor index (SVI) and the energy of germination (GE) were estimated.

1. Germination percentage (GP) was calculated using the following formula: Germination percentage $(\mathrm{GP})=$ number of germinated seeds $/$ total number of

$$
\text { seeds } \times 100
$$

2. Seed germination index (SGI) was calculated according to the following equation (Scoot et al., 1984):

Where,

$$
\mathrm{SGI}=\Sigma \mathrm{Ti} \mathrm{Ni} / \mathrm{S}
$$

$\mathrm{Ti}=$ is the number of days after sowing

$\mathrm{Ni}=$ is the number of seeds germinated on day $\mathrm{i}$

Egypt. J. Bot., Vol. 55, No. 2 (2015) 
$\mathbf{S}=$ is the total number of seeds planted

3. Energy of germination (GE) was recorded according to Farooq et al. (2005) at the $7^{\text {th }}$ day after sowing. It is the percentage of germinating seeds (GP) seven days after sowing relative to the total number of seeds tested (TNST).

\section{GE $=$ GP (7th day) / TNST}

4. The seedling vigor index was calculated according to equation (Orchard 1977).

Seedling vigor index $(\mathrm{SVI})=[$ seedling length $(\mathrm{cm}) \times$ germination percentage $]$.

The average means of growth parameters was carried out in four replicates and subjecting to analysis of variance and treatment means according to were computed Duncan's multiple range test (DMRT) at $P=0.05$.

\section{Results and Discussion}

All soils (Table 1) are of the sandy loamy, little alkaline type. The soils from which isolates 1 (Bacillus subtilis) and 2 (Esherichia coli) were isolated showed the highest value $\left(38,000 \mu \mathrm{mho} \mathrm{cm}^{-1}\right)$ of electric conductivity. Intermediate values of electric conductivity $(21,000$ and $10,000 \mu \mathrm{mho} \mathrm{cm}-1)$ were estimated for the soil concerned with the isolation of isolates 5 (Bacillus subtilis), 3 (Bacillus megaterium) and 4 (Micrococcous sp.). Lower values of EC (4,000 and $1,800 \mu \mathrm{mho} \mathrm{cm}^{-1}$ ) were recorded for the soils concerned with isolates 9, 10 (Bacillus subtilis) and 6 (Micrococcous sp.), 7 (Sporosarcia sp.). All isolates investigated were able to promote the seed germination of the test species (Parkinsonia aculeata).

The germination percentages (Table 2) gave the values of $38 \%$ for isolate 1 while the percentage of 32 was attained by both 2 and 4 isolates in comparison to the control one ( $8 \%$ ). Higher germination percentages (40, 42, 44 and 48) were attained by isolates $8,5,9,10,6$ and 7 , respectively. Highest germination index (10.42) was recorded for isolate 6 (Micrococcous sp.). Data elucidated that isolate 7 (Sporosarcia sp.) was distinguished by giving the highest values of germination percentage, seed vigor index (83.04), and energy of germination (1.96) at the $7^{\text {th }}$ day of the experiment.

Data indicated that the highest germination percentages (44 and 48) were monitored for the seeds soaked in the filtrates of Micrococcous sp. and Sporosarcia sp. of isolates 6 and 7 that inhabit the soils with low salt content. In all treatments; including the control, the shoot height was much longer and heavier than the root depth (Fig. 1). The highest value of R/S ratio (0.55) was achieved by isolate 8 (Bacillus subtilis) on the basis of length (Fig. 2). On the other hand, the highest dry weight of the root was monitored for the seeds soaked in the filtrate of isolate 8 (from Ohod Mountain) whereas the highest shoot dry weight was given by isolate 10 (Bacillus subtilis) isolated from Al-Awaly site. 
TABLE 1. Bacterial isolates, soil texture, $\mathrm{pH}$ and electric conductivity of the studied soils.

\begin{tabular}{|c|c|c|c|c|c|c|c|c|c|c|}
\hline \multirow[b]{2}{*}{$\begin{array}{c}\text { Isolate } \\
\text { no. }\end{array}$} & \multirow[b]{2}{*}{ Isolates } & \multirow[b]{2}{*}{$\begin{array}{c}\text { Site of } \\
\text { isolation }\end{array}$} & \multicolumn{6}{|c|}{ Soil physical properties } & \multirow[b]{2}{*}{$\mathbf{p H}$} & \multirow{2}{*}{$\begin{array}{c}\text { EC } \\
\left(\mu \mathbf{m h o}^{-1}\right. \\
\left.\mathbf{c m}^{-1}\right)\end{array}$} \\
\hline & & & Texture & Grave & $\begin{array}{c}\text { Coarse } \\
\text { sand } \\
(\%)\end{array}$ & $\begin{array}{c}\text { Fine } \\
\text { sand } \\
(\%)\end{array}$ & $\begin{array}{l}\text { Clay } \\
(\%)\end{array}$ & $\begin{array}{l}\text { Silt } \\
(\%)\end{array}$ & & \\
\hline 1 & $\begin{array}{l}\text { Bacillus } \\
\text { subtilis }\end{array}$ & $\begin{array}{l}\text { Qurban } \\
\text { El Nazel }\end{array}$ & \multirow{10}{*}{ 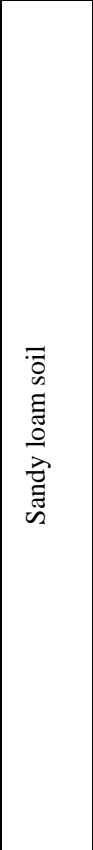 } & 0.00 & 27.61 & 38.60 & 20.2 & 13.54 & 8.57 & 38,000 \\
\hline 2 & $\begin{array}{l}\text { Esherichia } \\
\text { coli }\end{array}$ & $\begin{array}{l}\text { Qurban } \\
\text { El Nazel }\end{array}$ & & 0.00 & 27.61 & 38.60 & 20.2 & 13.54 & 8.57 & 38,000 \\
\hline 3 & $\begin{array}{c}\text { Bacillus } \\
\text { megaterium }\end{array}$ & $\begin{array}{c}\text { Eastern } \\
\text { Hara }\end{array}$ & & 4.37 & 22.96 & 46.23 & 13.04 & 13.40 & 8.23 & 10,000 \\
\hline 4 & $\begin{array}{l}\text { Micrococcous } \\
\text { sp. }\end{array}$ & $\begin{array}{c}\text { Eastern } \\
\text { Hara }\end{array}$ & & 4.37 & 22.96 & 46.23 & 13.04 & 13.40 & 8.23 & 10,000 \\
\hline 5 & $\begin{array}{l}\text { Bacillus } \\
\text { subtilis }\end{array}$ & $\begin{array}{c}\text { Western } \\
\text { Hara }\end{array}$ & & 5.10 & 25.9 & 40.80 & 14.9 & 13.30 & 8.05 & 21,000 \\
\hline 6 & $\begin{array}{l}\text { Micrococcous } \\
\text { sp. }\end{array}$ & $\begin{array}{c}\text { Al- } \\
\text { Awaly }\end{array}$ & & 8.30 & 32.89 & 36.70 & 11.47 & 10.64 & 8.54 & 1,800 \\
\hline 7 & $\begin{array}{l}\text { Sporosarcia } \\
\text { sp. }\end{array}$ & $\begin{array}{c}\text { Al- } \\
\text { Awaly }\end{array}$ & & 8.30 & 32.89 & 36.70 & 11.47 & 10.64 & 8.54 & 1,800 \\
\hline 8 & $\begin{array}{l}\text { Bacillus } \\
\text { subtilis }\end{array}$ & $\begin{array}{l}\text { Al- } \\
\text { Awaly }\end{array}$ & & 8.30 & 32.89 & 36.70 & 11.47 & 10.64 & 8.54 & 1,800 \\
\hline 9 & $\begin{array}{l}\text { Bacillus } \\
\text { subtilis }\end{array}$ & $\begin{array}{c}\text { Ohod } \\
\text { mountain }\end{array}$ & & 8.50 & 25.95 & 32.00 & 16.05 & 17.50 & 8.40 & 4,000 \\
\hline 10 & $\begin{array}{l}\text { subtilis } \\
\text { Bacillus }\end{array}$ & $\begin{array}{c}\text { Ohod } \\
\text { mountain }\end{array}$ & & 8.50 & 25.95 & 32.00 & 16.05 & 17.50 & 8.40 & 4,000 \\
\hline
\end{tabular}

TABLE 2. Germination percentage, index, vigor, and energy of germination for Parkinsonia aculeata seeds after soaking in bacterial filtrates. In columns, means followed by common letters are not significantly different at 5\% level by LSD. GP, Germination percentage; SGI, seed germination Index; GE, Energy of Germination; SVI, Seedling Vigor Index.

\begin{tabular}{|c|c|c|c|c|}
\hline \multirow{2}{*}{ Bacterial isolate filtrate } & \multicolumn{4}{|c|}{ Seed Germination Parameters } \\
\cline { 2 - 5 } & GP & SGI & SVI & GE (at 7 d $^{\text {th }}$ \\
\hline Control (s.d.w.) & $8^{\mathrm{d}} \pm 3.27$ & $1.97^{\mathrm{c}} \pm 0.77$ & $13.6^{\mathrm{e}} \pm 5.55$ & $0.32^{\mathrm{d}} \pm 0.13$ \\
\hline 1 & $38^{\mathrm{bc}} \pm 5.16$ & $9.07^{\mathrm{ab}} \pm 1.14$ & $66.7^{\mathrm{bcd}} \pm 11.25$ & $1.52^{\mathrm{bc}} \pm 0.21$ \\
\hline 2 & $32^{\mathrm{c}} \pm 3.27$ & $7.63^{\mathrm{b}} \pm 0.71$ & $54.4^{\mathrm{d}} \pm 7.28$ & $1.28^{\mathrm{c}} \pm 0.13$ \\
\hline 3 & $44^{\mathrm{ab}} \pm 9.79$ & $10.35^{\mathrm{a}} \pm 2.26$ & $75.8^{\mathrm{ab}} \pm 17.99$ & $1.76^{\mathrm{ab}} \pm 0.39$ \\
\hline 4 & $32^{\mathrm{c}} \pm 3.27$ & $7.33^{\mathrm{b}} \pm 0.57$ & $58.7^{\mathrm{cd}} \pm 5.27$ & $1.28^{\mathrm{c}} \pm 0.13$ \\
\hline 5 & $42^{\mathrm{ab}} \pm 5.16$ & $10.14^{\mathrm{a}} \pm 1.36$ & $73.8^{\mathrm{abc}} \pm 9.72$ & $1.69^{\mathrm{ab}} \pm 0.24$ \\
\hline 6 & $44^{\mathrm{ab}} \pm 3.27$ & $10.42^{\mathrm{a}} \pm 0.81$ & $78.4^{\mathrm{ab}} \pm 5.82$ & $1.78^{\mathrm{ab}} \pm 0.16$ \\
\hline 7 & $48^{\mathrm{a}} \pm 3.27$ & $10.12^{\mathrm{a}} \pm 1.64$ & $83.04^{\mathrm{a}} \pm 5.65$ & $1.96^{\mathrm{a}} \pm 0.14$ \\
\hline 8 & $40^{\mathrm{abc}} \pm 7.30$ & $8.87^{\mathrm{ab}} \pm 1.40$ & $71.2^{\mathrm{abc}} \pm 12.99$ & $1.62^{\mathrm{abc}} \pm 0.32$ \\
\hline 9 & $42^{\mathrm{ab}} \pm 5.16$ & $9.14^{\mathrm{ab}} \pm 1.34$ & $75.2^{\mathrm{ab}} \pm 9.24$ & $1.69^{\mathrm{ab}} \pm 0.24$ \\
\hline 10 & $42^{\mathrm{ab}} \pm 5.16$ & $8.37^{\mathrm{ab}} \pm 1.67$ & $67.2^{\mathrm{abcd}} \pm 8.26$ & $1.69^{\mathrm{ab}} \pm 0.24$ \\
\hline
\end{tabular}

(s.d.w. = sterile dist. Water)

Egypt. J. Bot., Vol. 55, No. 2 (2015) 
The present investigation clarified the importance of soil bacteria inhabiting the arid zones; especially Micrococcous sp., Sporosarcia sp. and Bacillus subtilis in seed germination promotion through the dissolution of the seed coat. On the contrary, the effect of extracts of Bacillus subtilis in the inhibition of seed germination of Sorghum halepense and Amaranthus hybridis was documented (Mendoza et al., 2012). Maximum seed germination and maximum shoot and root length of Pennisetum americanum was recorded in the combination of Bacillus subtilis and Aspergillus flavus in a pot experiment (Bhushan et al., 2013). Authors added that Bacillus subtilis is able to reduce the seed - borne mycoflora of $P$. americanum. Ajilogba et al. (2013) found that all Bacillus spp. produce Indole Acetic Acid which supported growth of tomato. Production of IAA helps to increase the root dry weight and thereby increases the plant's ability to uptake N, $\mathrm{P}, \mathrm{K}, \mathrm{Ca}$ and $\mathrm{Mg}$ compared to the control (Etesami et al., 2009). Lamasal et al., (2012) investigated that $B$. licheniformis and $B$. subtilis both produce $B$-glucanose, siderophene and auxins, they were also involved in phosphate solubilization, which led up to $20 \%$ increase in leaf, stem and root growth of red pepper and tomato. In a similar trial that agrees with ours, the effect of Bacillus licheniformis in promoting the seed germination and the seedling growth of the arid zone species; Acacia senegal was proved (Singh et al., 2011).

In an experiment using the plant growth - promoting rhizobacteria, Gholami et al. (2009) concluded that the seed inoculation with bacteria significantly enhanced the seed germination, the seedling vigor, leaf and shoot dry weight, and the leaf area of maize. Also, Bacillus sp. and Mycobacterium sp. greatly increased the stem length of tomato (Tabli et al., 2014). Pathak et al. 2013 reported that the seed germination and plant growth of guava recorded positive response when inoculated with plant growth promoting bacteria (PGPB) combined with Azotobacter, Chroococcum and farmyard manure (FYM). The possible reason for better plant growth and germination can be attributed to maximum and early bacterization near the root zone which induces germination by inducing root inducing substances (Wani et al., 1988). Similar reports have been made by Nath and Koria (2000) in ginger (Zingiber officinale Rosc.).

The present investigation showed that greater germination of the tested seeds ouccrhed in soils with high salinity. This observaian can tradicts the results of Bojovic et al. (2010) who reported that seeds of all species belonging to Brassicaceae and Solanaceae germinate only in the low $\mathrm{NaCl}$ concentration. They added that all examined seeds germinate in great numbers after rinsing in distilled water. Naturally, the seeds of arid zones, such as Parkinsonia aculeata inhabiting the soils with high salinity always germinate in the rainy season and after the dilution of salts in soil. Under laboratory conditions, seed treatment with the test strain improved seed germination and seedling emergence over the control. Bacteria are known to produce different metabolites like IAA, GA and cytokinin - like substances, which can exert positive effect on seed germination and radicle length (Minax, 2012). Significant increase in seedling vigor could be due to better synthesis of auxins (Bharathi et al., 2004).

Egypt. J. Bot., Vol. 55, No. 2 (2015) 


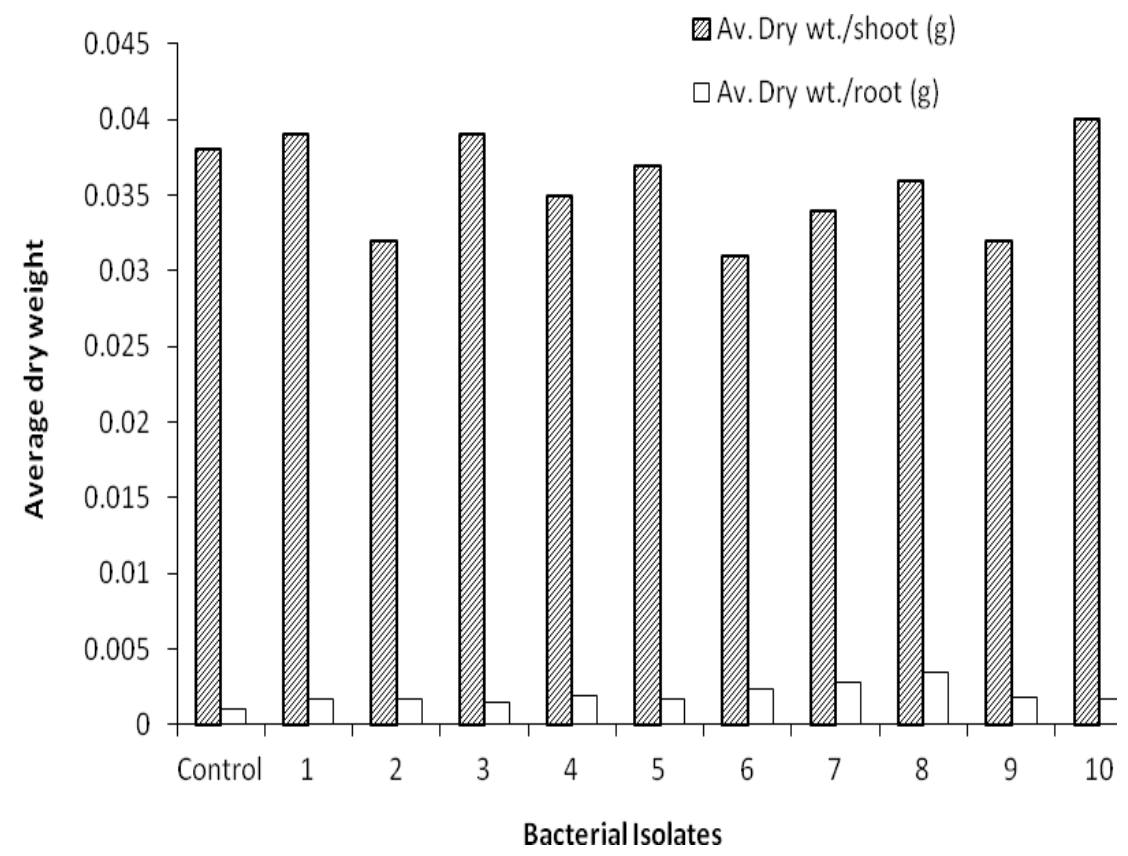

Fig.1. Root and shoot dry weights of 7 days old Parkinsonia seedlings after soaking in different bacterial filtrates

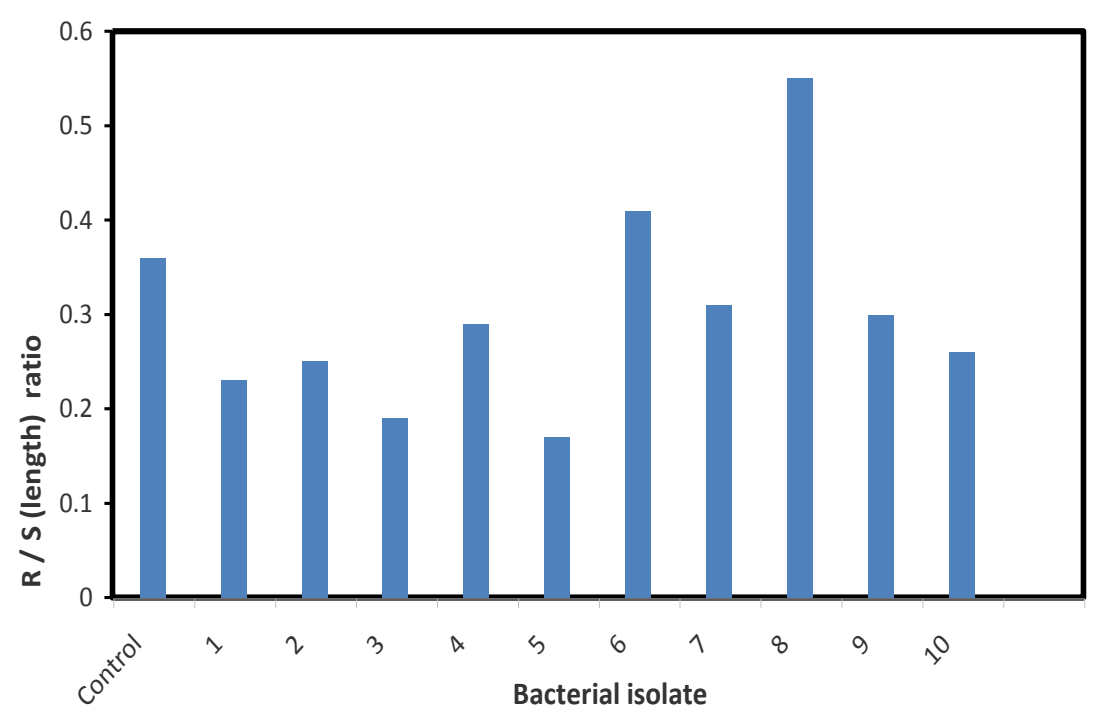

Fig. 2. Root / Shoot ratio (R/S) on basis of length of 7 days old Parkinsonia seedlings after soaking in different bacterial filtrates.

Egypt. J. Bot., Vol. 55, No. 2 (2015) 


\section{References}

Ajilogba, C.F., Babalola, O.O. and Ahmad, F. (2013) Antagonistic effects of Bacillus species in biocontrol of tomato Fusarium wilt., Ethno. Med., 7 (3), 205-216.

Bergey, D.H. Krieg, N.R. and Holt, J.G. (1984) “Bergey's Manual of Systematic Bacteriology”, Williams \& Wilkins Publication Co., Michigan, USA.

Bharathi, R., ViveKananthan, R. Harish, S., Ramanathan, A. and Samiyappan, R. (2004) Rhizobacteria-based bio-formulations for the management of fruit rot infection in Chillies, Crop Protec., 23, 835-843.

Bhushan, G., Chhangani, S., Singh, J. and Singh, A.P. (2013) Antagonistic effects of Bacillus subtilis and Pseudomonas fluorescens against seed-borne mycoflora of Pennisetum americanum, G- Journal of Environmental Science and Technology, 1(3), 71-75.

Bojovic, B., Delic, G., Topuzovic, M. and Stankovic, M. (2010) Effects of $\mathrm{NaCl}$ on seed germination in some species from families Brassicaceae and Solanaceae, Kragujevec Journal of Science, 32, 83-87

Das, A.C. and Kole, S.C. (2006) Effect of some root associative bacteria on germination of seeds, nitrogenase activity and dry matter production by rice plants, J. of Crop and Weed, 2 (2), 47-51.

Etesami, H., Alikhani, H.A., Jadidi, M. and Aliakbari, A. (2009) Effect of superior IAA producing rhizobia on $\mathrm{N}, \mathrm{P}, \mathrm{K}$ uptake by wheat grown under greenhouse conditions, World J. Appl. Sci., 6, 1629-1633.

Farooq, M., Basra, S.M.A. and Hafeez, K. (2005) Thermal hardening: A new seed vigor enhancement tool in rice, Acta Botanica Sinica., 47 (2), 187-193.

Fordham, A.J. (1965) Germination of woody legume seeds within impermeable seed coats, Bulletin of Popular Information of the Arnold Arboretum, Harvard University. 25 (1).

Gholami, A., Shahsavani, S. and Nezarat, S. (2009) The effect of plant growth promoting rhizobacteria (PGPR) on germination, seedling growth and yield of maize. World Academy of Science and Technology, 3, 01-26.

International Seed Testing Association (ISTA) (1993) International rules for seed testing, Seed Science and Technology, 21, 160-186.

International Seed Testing Association (ISTA) (1999) International rules for seed testing, Seed Science and Technology, 27, 340.

Josic, S.M.D., Pavlovic, S., Drazic, S., Postic, D., Popovic, T. and Stojanovic, S. (2013) The effect of IAA producing Bacillus sp. iQ3 strain on marshmallow seed germination, Bulg. J. of Agric. Sci., 19 (3), 572-577. 
Lamasal, K., Kim, S.W., Kim, Y.S. and Lee, Y.S. (2012) Application of rhizobacteria for plant growth promotion effect and biocontrol of Anthraconse caused by Colletotrichum acutatum on pepper, Mycobiol., 40, 244-251.

Minax, L., N., Yadan, R.C. and Saxena, J. (2012) Characterization of multifaceted Bacillus sp. RM-2 for its use as plant growth promoting bioinoculant for crops grown in semiarid deserts, Appl. Soil Ecol., 59, 124-135.

Mendoza, E.K.M., Violante, H.G.M., Inocencio, C.M., Salsedo, G.O., Madrigal, H. C., Portugal, V.O. and Perez, M. V. (2012) Effects of Bacillus subtilis extracts on weed seed germination of Sorghum halepense and Amaranthus hybridus, Afr. J. of Microbiol. Res., 6 (9), 1887-1892.

Nath, B. and Koria, B. N. (2000) Studies on effect of biofertilizers in ginger, Ind. $J$. Hortic., 57, 168-171.

Orchard, T. (1977) Estimating the parameters of plant seedling emergence, Seed Sci. and Tech., 5, 61-69.

Pathak, D.V., Singh, S. and Saini, R.S. (2013) Impact of bio-inoculants on seed germination and plant growth of guava (Pisidium guajava), Glob. J. Wood Sci. Forest. Wildl., 1(1), 15-17.

Scott, S.J., Jones, R.A. and Williams, W.A. (1984) Review of data analysis methods for seed germination, Crops Sci., 24, 1192.

Sheikh, H.M. (2010) Antimicrobial activity of certain bacteria and fungi isolated from soil mixed with human saliva against pathogenic microbes causing dermatological diseases, Saudi J. Biol. Sci., 17(4), 331-339.

Singh, S.K., Pancholy, A. and Pathak, R. (2011) Effect of plant growth promoting rhizobia on seed germination and seedling traits in Acacia Senegal, Ann. Forest Res., 54(2), 161-169.

Sneath, P.H.A, Mair, N.S., Sharpe, M.E. and Holt, J.G. (1986) "Bergey's Manual of Systematic Bacteriology",Williams \& Wilkins Publication Co., Michigan, USA. P. 1325-1329.

Tabli, N., Nabti, E.H., Dahel, D., Mokrane, N., Manyani, H., Dary, M. and Megias, M. G. (2014) Impact of diazotrophic bacteria on germination and growth of tomato, with bio-control effect, isolated from Algeria soil, J. Ecol. Health and Environ., 2 (1), 1-7.

Umechuruba C.I and Nwachukwa E.O. (1997) The effect of filtrates of seed-borne fungi of African yam bean on seed germination and seedling development. Glob. J. Pure and Appl. Sci., 3, 165-176.

Vastakaite, V. and Buzaite, O. (2011) Plant growth promoting properties of culturable phylloepiphytic pine bacteria, Biol., 57(1), 33-36.

Wani, S.P., Chandrapalaiah, S., Zambre, M.A. and Lee, K.K. (1988) Association between $\mathrm{N}_{2}$ fixing bacteria and pearl millet plants-Response, mechanism and resistance, Plant Soil., 110, 284-302.

Egypt. J. Bot., Vol. 55, No. 2 (2015) 
Yadan, J., Verma, J.P. and Tiwari, K.N. (2010) Effect of plant growth promoting rhizobacteria on seed germination and plant growth of Chickpea (Cicer arietinum L.) under in vitro conditions, Biol. Forum., 2(2), 15-18.

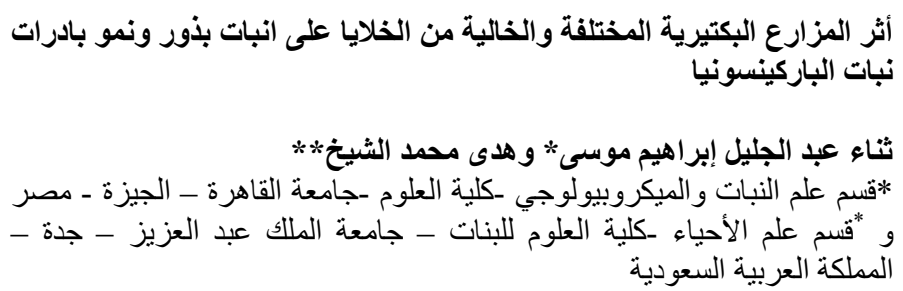

تنتج الأنواع البكتيرية العديد من النواتج الأيضية المفيدة لنمو النبات وبقائه كما

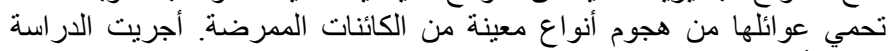

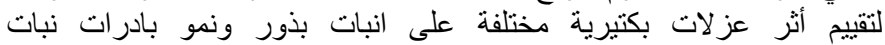

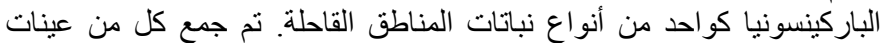

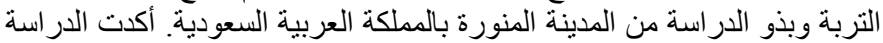

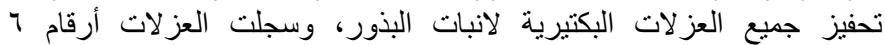

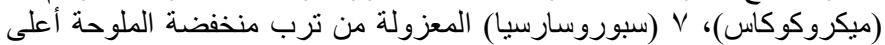

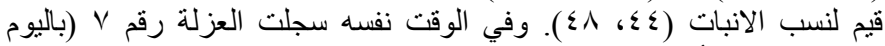

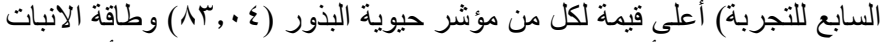

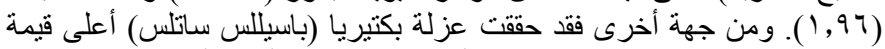

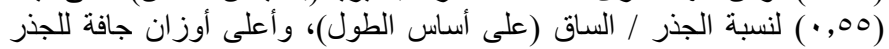

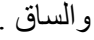

